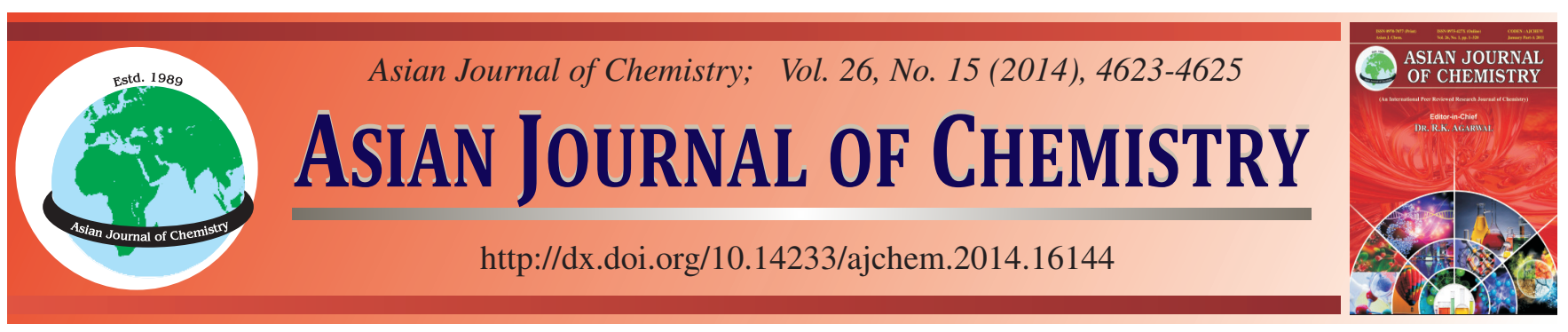

\title{
Analysis on Chemical Reaction Kinetics for Phosphorus Removal of Sewage in Horizontal Subsurface Flow Constructed Wetlands
}

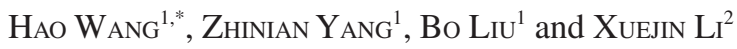

${ }^{1}$ College of Civil and Architecture Engineering, Hebei United University, Tangshan, P.R. China

${ }^{2}$ Department of Foreign Languages, Tangshan College, Tangshan, P.R. China

*Corresponding author: E-mail: wanghao1689@gmail.com

\begin{abstract}
Different subsurface flow constructed wetlands were adapted to advanced treat sewage treatment plant secondary effluent and analyze the effect of phosphorus removal and its reaction kinetics model. The results showed that horizontal subsurface flow wetland removal of phosphorus in sewage exhibited a good removal characteristic and compared with horizontal zeolite wetland, horizontal limestone wetland exhibited better phosphorus removal effect, the removal rate basically retained at $66.3 \pm 3.32$ to $92.0 \pm 4.82 \%$. In addition, based on the reaction dynamics simulation analysis, the results showed that two subsurface flow wetlands were in line with the characteristics of firstorder kinetics equation, i.e. phosphorus removal process was basically carried out to a reaction.
\end{abstract}

Keywords: Subsurface constructed wetlands, Phosphorus, Secondary effluent from sewage treatment plant, Reaction kinetics model.

ᄂ - - - - - - - - - - - - - - - - - - - - - - - -

\section{INTRODUCTION}

Constructed wetland is an artificial constructed and regulated wetland system and its eco-systems in the physical, chemical and biological role of the optimal combination are applied for wastewater treatment ${ }^{1-5}$. The method for COD and $\mathrm{NH}_{3}-\mathrm{N}$ removal effect is obvious, but also has water effects and stability, low running costs, ease of operation and management of security. The technology has been in the global environmental field has attracted much attention ${ }^{6-9}$. Kinetic model is widely studied and the most widely used of a class of mathematical models constructed wetland. Europe and other developed countries have the basic design equations which are widely used in the design of wetlands and predict contaminant removal ${ }^{10-13}$. For wetland dynamics model, especially for horizontal flow pattern and completely regular size grading wetlands simulate and study the multiple ${ }^{14-17}$. At present, the wetland is mainly based on mathematical models of statistical principles kinetics and ecological dynamics ${ }^{18}$. Therefore, the horizontal flow and vertical flow test device contaminant degradation kinetics model to study, to provide subsurface flow constructed wetland system design and engineering applications to provide a theoretical basis. This test is mainly subsurface wetland study the effect of phosphorus removal and use of wetland dynamics model analysis of the effects of phosphorus removal, in order to identify subsurface flow wetland for wastewater phosphorus removal law.

\section{EXPERIMENTAL}

The experiment was carried out in a laboratory with a controlled environment in Tangshan of P.R. China. The horizontal subsurface wetland systems consisted of two $1 \mathrm{~m}^{2}$ wetland mesocosms $(1.6 \mathrm{~m}$ long $\times 0.6 \mathrm{~m}$ large $\times 0.6 \mathrm{~m}$ deep $)$. Gravel, with a particle diameter of $15-25 \mathrm{~mm}$, was laid at the bottom of the two systems and the depth was $0.10 \mathrm{~m}$. Zeolite and limestone were laid, respectively at the middle layers of the two wetlands, both with particle diameters of 6-10 mm and depth of $0.20 \mathrm{~m}$. The upper beds were consisted of lytag with a depth of $0.15 \mathrm{~m}$ and particle diameter of 3-5 $\mathrm{mm}$. The sieving soils were laid at the uppermost layers, the depth of which was $0.05 \mathrm{~m}$. Phragmites and reed mace were planted in the soils with the interplanting ratio of $1: 1$.

Influent quality: The raw wastewater, secondary effluent of wastewater treatment plants, was collected from wastewater treatment plant in Tangshan. The composition of the influent used in all experiments is shown in Table- 1 .

\begin{tabular}{lc}
\multicolumn{2}{c}{ TABLE-1 } \\
\multicolumn{3}{c}{ CHARACTERISTICS OF THE WASTEWATER } \\
\multicolumn{1}{c}{ SAMPLE USED IN THE EXPERIMENTS } \\
\hline \multicolumn{1}{c}{ Parameter } & Concentration \\
\hline $\mathrm{pH}$ & $6.5-8.0$ \\
Ammonia nitrogen $\left(\mathrm{NH}_{3}-\mathrm{N}\right)$ & $24.5-32.7\left(\mathrm{mg} \mathrm{L}^{-1}\right)$ \\
Total nitrogen $(\mathrm{TN})$ & $37.7-45.1\left(\mathrm{mg} \mathrm{L}^{-1}\right)$ \\
Total phosphorus (TP) & $4.5-5.0\left(\mathrm{mg} \mathrm{L}^{-1}\right)$ \\
\hline
\end{tabular}




\section{RESULTS AND DISCUSSION}

As shown in Fig. 1, with the wetlands gradually extended running time, a variety of wetland total phosphorus removal, there was greater disagreement: horizontal subsurface flow wetland removal of total phosphorus showed a significantly higher vertical flow wetland features. In this stable operation phase, two kinds of wetlands for phosphorus removal size order: horizontal limestone wetland > horizontal zeolite wetland and the two removal effects exhibited a significant difference $(\mathrm{p}<0.05)$. In which the optimal horizontal zeolite wetland total phosphorus removal rate remained at $66.3 \pm 3.32$ $92.0 \pm 4.82 \%$. In addition, horizontal zeolite wetland also showed similar removal trend with the limestone wetland. Based on the above data, it is observed that in the initial stage, due to wetland substrate adsorption, two kinds of wetlands have shown a good removal efficiency for total phosphorus, but over time, gradually become saturated wetland substrate, total phosphorus removal rate gradually stabilized. This is probably due to horizontal flow wetland can form more in line with the growth of phosphate accumulating bacteria environment, improve the phosphate accumulating bacteria degrade the efficiency of phosphorus. While the vertical flow wetland during the operating phase of total phosphorus removal rate is relatively low, which may be due to the vertical flow greater degree of influence by the external environment, so that the vertical flow wetland of total phosphorus removal rate decreases.

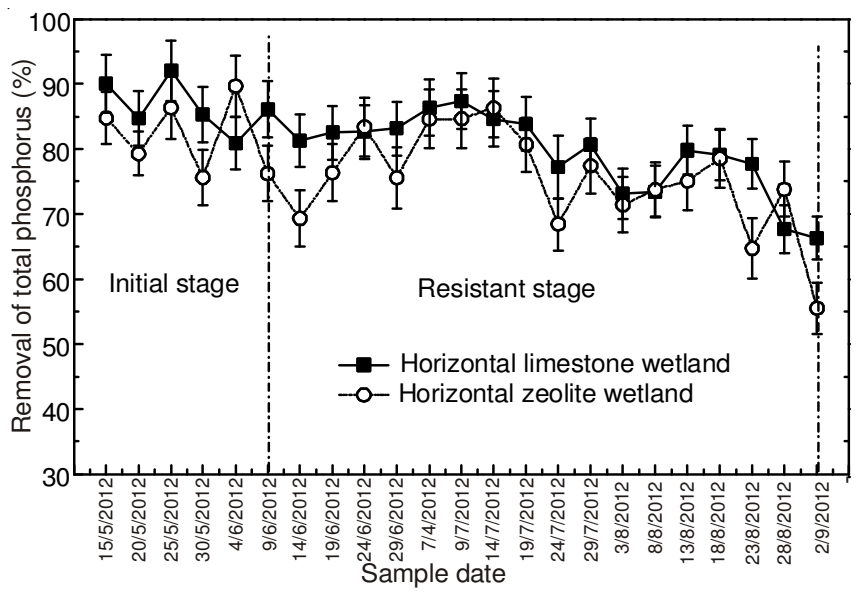

Fig.1. Removal effect on total phosphorus in every wetland under the same hydraulic loading (percentages of total phosphorus removal is shown as mean \pm s.d., $\mathrm{n}=3$; significant differences were assessed by the LSD-test

Total phosphorus degradation effect on the reaction kinetics model simulation

In the pilot phase, the raw water total phosphorus concentration $1.03 \pm 0.22 \mathrm{mg} / \mathrm{L}(\mathrm{n}=5)$. Two kinds of subsurface wetland effluent total phosphorus concentration $\left(\mathrm{C}_{\text {out }}\right)$ were measured and data processing of the water, meanwhile, the running time for the 5 days. According to the subsurface wetlands total phosphorus effluent concentration $\mathrm{C}_{\text {out }}$ and hydraulic retention time, draw $\ln \mathrm{C}_{\text {out }}-\mathrm{t}$ and $1 / \mathrm{C}_{\text {out }} \mathrm{t}$ curve and determine the reaction kinetics progression.
As shown in Figs. 2 and 3, two kinds of subsurface flow constructed wetlands a kinetic equation for the correlation coefficient greater than 0.97 , which can show a subsurface flow wetland reaction kinetics simulation applications can better reflect the system of total phosphorus degradation rule, namely the undercurrent of wetland treatment efficiency of total phosphorus extension with hydraulic retention time (HRT) is gradually increased. However, in the two kinetic simulation, four kinds of subsurface flow wetland linear correlation coefficient is less than the index of the analog simulation of the correlation coefficient, i.e., $1 / \mathrm{C}_{\text {out }} \mathrm{t}$ figure more close to the curve, so you can determine the initial subsurface flow wetland above two comply with a kinetic equation characteristics, namely its total phosphorus removal process is basically carried out only to a reaction.
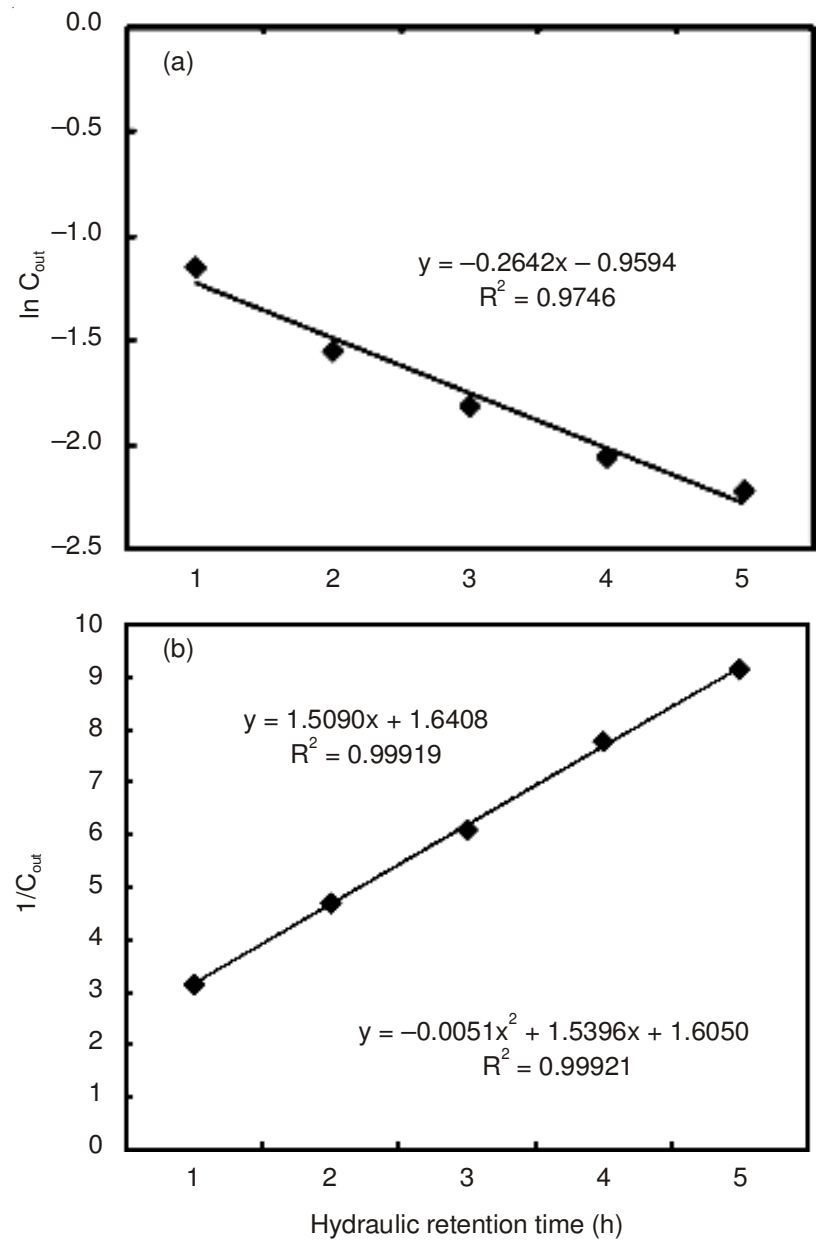

Fig. 2. Simulating equation of reaction kinetic total phosphorus degradiation for horizontal-limestone wetland

In addition, in a reaction, the linear analog equation correlation coefficient $\mathbf{R}^{2}$ order: Horizontal-zeolite wetlands (0.9895) > horizontal-limestone wetlands (0.9746); half-life $\mathrm{t}_{1 / 2}$ order: Horizontal limestone wetlands $(2.62 \mathrm{~h})<$ horizontal zeolite wetlands $(3.81 \mathrm{~h})$. As can be seen from the above data, the level of-zeolite wetlands after fitting the correlation coefficient is superior to the other three wetlands, water effect from a practical point of view, horizontal limestone wetland total phosphorus removal effect is best, which also showed horizontal limestone wetland degradation reaction greater than the proportion of total phosphorus three other wetlands. Meanwhile, the removal of total phosphorus, the horizontal-lime 

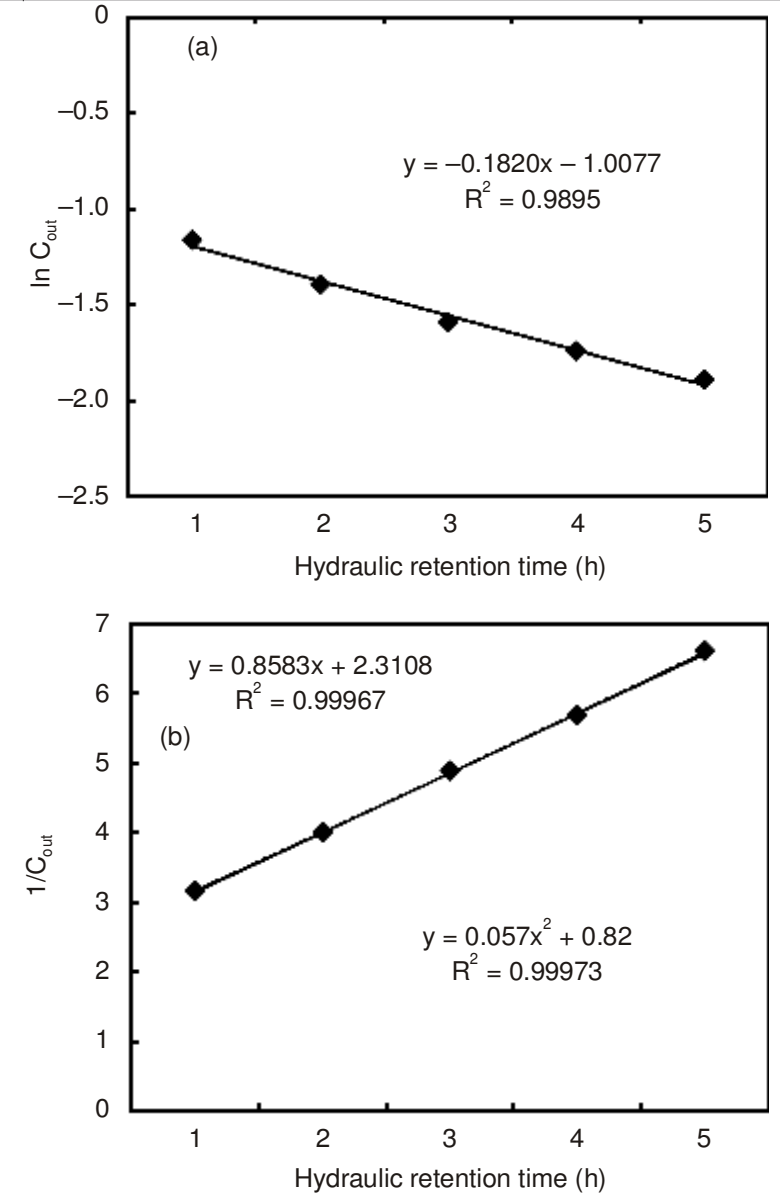

Fig. 3. Simulating equation of reaction kinetic total phosphorus degradiation for horizontal-zeolite wetland

stone wet manifest in good removal of its nature. In addition, horizontal-zeolite wetlands two reactions fit better than the horizontal limestone wetlands, but the level-zeolite wetlands two reaction half-life than the horizontal-limestone wetlands also slightly slower, but the actual effect of the water, the level of-limestone wetland total phosphorus removal is better than horizontal-zeolite wetlands, therefore, with the level-compared to zeolite wetlands, horizontal-limestone wetland two reactions better. This is confirmed by level-limestone wetland total phosphorus removal is better than the other three wetlands results.

\section{Conclusion}

Two kinds of subsurface constructed wetlands select the same hydraulic loading conditions of operation, two of its sewage treatment plant effluent phosphorus removal with good results. Compared with the horizontal limestone wetland, horizontal zeolite wetlands showed a better for phosphorus removal, two of its wastewater treatment plant effluent total phosphorus removal rate remained at $66.3 \pm 3.32-92.0 \pm$ $4.82 \%$. According to the simulation results, two kinds of subsurface wetland characteristics comply with a kinetic equation, namely its phosphorus removal process can basically be considered only to a reaction. More the depth of reaction kinetics is also the need for further trials research.

\section{ACKNOWLEDGEMENTS}

The financial support of this research by Hebei Province Science and Technology Project (13273608) and Hebei Construction Science and Technology Research Program (2013-143) are gratefully acknowledged.

\section{REFERENCES}

1. N. Mehrdadi, A. Rahmani, A.A. Azimi and A. Torabian, Asian J. Chem., 21, 5245 (2009).

2. H. Wang, X.W. He, T.Q. Liu and C.H. Zhang, Fresenius Environ. Bull., 20, 2890 (2011).

3. H. Wang and L. Zhang, Asian J. Chem., 24, 5299 (2012).

4. H. Wang, X.J. Li and L. Zhang, Asian J. Chem., 25, 2703 (2013).

5. G.D. Ji, T.H. Sun, Q.X. Zhou, X. Sui, S. Chang and P. Li, Ecol. Eng., 18, 459 (2002).

6. Y.F. Lin, S.R. Jing, D.Y. Lee and T.W. Wang, Aquaculture, 209, 169 (2002).

7. F. Rivera, A. Warren, C.R. Curds, E. Robles, A. Gutierrez, E. Gallegos and A. Calderon, Water Sci. Technol., 35, 271 (1997).

8. C.J. Richardson and S.S. Qian, Environ. Sci. Technol., 33, 1545 (1999).

9. N. Korboulewsky, R.Y. Wang and V. Baldy, Bioresour. Technol., 105, 9 (2012).

10. C.C. Tanner, J.P.S. Sukias and M.P. Upsdell, Water Res., 32, 3046 (1998).

11. G.D. Ji, T.H. Sun, Q.X. Zhou, X. Sui, S. Chang and P. Li, Ecol. Eng., 18, 459 (2002).

12. R.M. Gersberg, B.V. Elkins and C.R. Goldman, Water Res., 17, 1009 (1983).

13. F. Masi, B. El Hamouri, H. Abdel Shafi, A. Baban, A. Ghrapi and M. Regelsberger, Water Sci. Technol., 61, 97 (2010).

14. S. Naylor, J. Brisson, M.A. Labelle, A. Drizo and Y. Comeau, Water Sci. Technol., 48, 215 (2003).

15. C. Platzer, Water Sci. Technol., 40, 777 (1999).

16. C. Sundberg, K. Tonderski and P.E. Lindgren, Water Sci. Technol., 56, 159 (2007).

17. M.A. Aon, M.N. Cabello, D.E. Sarena, A.C. Colaneri, M.G. Franco, J.L. Burgos and S. Cortassa, Appl. Soil Ecol., 18, 239 (2001).

18. S. Ayaz and I. Akca, Water Sci. Technol., 41, 69 (2000). 